\title{
Current state of zooplankton of Lake Munozero (Republic of Karelia, Russia)
}

\author{
Mariya T. Syarki, Yuliya Yu. Fomina
}

Northern Water Problems Institute of Karelian Research Center, Russian Academy of Sciences, ul. Aleksandra Nevskogo 50, Petrozavodsk, Republic of Karelia, 185030 Russia

*msyarki@yandex.ru

Received: 19.04.2019

Accepted: 11.06.2019

Published online: 17.01 .2020

DOI: $10.23859 /$ estr-190419

UDC 574.583:556.55(470.22)

ISSN 2619-094X Print

ISSN 2619-0931 Online

Translated by D.M. Martynova
The modern state and functioning of the zooplankton community of Lake Munozero has been assessed. The species composition and dominant zooplankton complex of Lake Munozero has not changed since the 1950s. The Shannon-Weaver index in terms of biomass corresponds to the oligo- and mesotrophic type of lakes in the northwestern and southern areas of the lake, respectively. Saprobity indicators refer to the $\beta$-mesosaprobic zone (moderately polluted water). Seasonal changes in the zooplankton community correspond to the dynamics common for the lakes of Karelia. Zooplankton community of the southern area of Lake Munozero is under anthropogenic load, this is expressed in noticeable differences in the species composition, Shannon-Weaver index, saprobity index, and in quantitative and functional characteristics.

Keywords: community structure, species diversity, ecosystem status, water quality, water bodies of Karelia.

Syarki, M.T., Fomina, Yu.Yu., 2020. Current state of zooplankton of Lake Munozero (Republic of Karelia, Russia). Ecosystem Transformation 3 (1), 11-18.

\section{Introduction}

Lake Munozero is located in the southern Karelia, Russia. The reservoir stands out among other lakes of the region. The lake water is weakly colored $(8 \mathrm{mg}$ $\mathrm{Pt} \cdot \mathrm{L}^{-1}$ scale, 8 points), it contains a small amount of humic organic substances and are relatively highly mineralized $\left(97.8 \mathrm{mg} \cdot \mathrm{L}^{-1}\right)$ in comparison with other water bodies of the Republic of Karelia. The mineralization of most Karelian lakes lies in the range of $15-40 \mathrm{mg}^{-\mathrm{L}^{-1}}$, on average, $25 \mathrm{mg} \cdot \mathrm{L}^{-1}$ (Filatov and Kukharev, 2013). The lake is stretched along north-southwards axis and has a complex two-bladed shape. The lake reaches have different depths and vary in level of anthropogenic load. The Spasskaya Guba village locates on the southern shore of the lake; in addition, the southern region of the lake is affected by the sewage of the Dvortsy and Marcialnye Vody health resorts. The northern shore of the lake belongs to the protected area of the Kivach State Nature Reserve. According to A.V. Sabylina and
O.I. Ikko (Sabylina and Ikko, 2019), the north-western reach of Lake Munozero has low $\mathrm{BOD}_{5}$ values $(0.58$ $\left.0.75 \mathrm{mg} \cdot \mathrm{L}^{-1}\right)$; in the southern part of the reservoir, these values are higher twofold $\left(0.69-2.12 \mathrm{mg}^{-\mathrm{L}^{-1}}\right)$. The content of suspended solids in the lake waters is low and varies from 0.6 to $2.0 \mathrm{mg} \cdot \mathrm{L}^{-1}$. The concentration of total phosphorus also varies significantly between regions. In the north-western part of the lake, it averages $8 \mu \mathrm{g} \cdot \mathrm{L}^{-1}$, in the southern part, $12 \mu \mathrm{g} \cdot \mathrm{L}^{-1}$. The concentration of total nitrogen in the north-western reach is $0.01-0.17 \mathrm{mg} \cdot \mathrm{L}^{-1}$, in the southern, $0.01-$ $0.24 \mathrm{mg} \cdot \mathrm{L}^{-1}$. In general, the north-western region of Lake Munozero corresponds to the oligotrophic type; in the southern region, the development of eutrophication processes is noted. Since the 1990s, the large-scale overgrowth of the littoral of the southern reaches of the lake is observed; therefore, in this part of the lake, the enrichment with organic matter and nutrients occurs not only due to the discharge of domestic wastewater, 
but also due to the process of decomposition of higher aquatic vegetation.

In recent decades, in Karelia, an increase in average annual air temperature, as well as in the annual amount of atmospheric precipitation have been observed (Nazarova, 2014), accompanied by a predominance of mild winters, weak freezing of the soil, and by an increase in runoff from wetlands in winter time (Kalinkina et al., 2019). Such environmental changes affect the functioning of aquatic communities. Thus, an increase in water color leads to a decrease in the productivity of lake phytoplankton (Jones, 1992), shrinkage of the body size of crustacean plankton (Soranno et al., 1993), and a decrease in the fish growth rate (Rask et al., 2000). A change in the temperature regime leads to a redistribution of certain groups and species of zooplankton (Izmest'eva et al., 2016; Lazareva and Sokolova, 2013), as well as to the shifts in their life cycles (Adrian et al., 2006). Therefore, the study of functioning of the zooplankton community has to be performed throughout the growing season, taking into account the seasonality of the processes.

The study aims to assess the current state and functioning of the zooplankton community of Lake Munozero.

\section{Materials and methods}

Lake Munozero belongs to the basin of the Shuya River and the watershed area of the Baltic Sea. The total area of the lake is $13.2 \mathrm{~km}^{2}$, the maximum depth is $55.0 \mathrm{~m}$, the average depth is $14.4 \mathrm{~m}$, the water volume is $0.19 \mathrm{~km}^{3}$ (Filatov and Kukharev, 2013).

The studies were conducted in May, July, and September 2018 at the stations located in the north-western (depth $39.5 \mathrm{~m}$ ) and southern (depth $19.0 \mathrm{~m}$ ) reaches of the lake. The samples were taken and processed using standard methods (Vinberg and Lavrentyeva, 1984). The zooplankton sampling has been performed by Juday net (opening diameter of $18 \mathrm{~cm}$, mesh size of $100 \mu \mathrm{m}$ ) in the water layers of $0-5 \mathrm{~m}, 5-10 \mathrm{~m}$, and $10 \mathrm{~m}$-bottom. The counting of organisms was carried out taking into account the sizesex-age groups. Taxonomic identification of species was performed according to the "Key to Zooplankton and Zoobenthos of the Fresh Waters of the European Part of Russia. Volume 1" (Alekseev and Tsalolikhin, 2010). The biomass was calculated according to the body size-body weight ratios for the studied groups of hydrobionts (Balushkina and Vinberg, 1979). The calculations were performed for each size-sex-age group of each species, then the obtained values were summarized by samples, and the weighted average has been calculated for particular station.

Production and functional characteristics were calculated by the physiological method using coefficients generally accepted for zooplankton (Vinberg and Lavrentyeva, 1984). The lower limit of dominance was set as $10 \%$ of the total abundance. The Shannon-Weaver diversity index was calculated for each station by season using the weighted average of the species biomass in the water column. The saprobity index was calculated taking into account the saprobic characteristics of species adjusted for the water bodies of Karelia (Kulikova, 1983).

\section{Results and discussion}

During the study period, 35 species and taxonomic groups with a rank below the genus (Copepoda 8 species, Cladocera -15 species, and Rotifera -12 species) have been registered in the pelagic zone of Lake Munozero (Table 1).

The number of species varied seasonally from $18-19$ in the spring up to $25-28$ in the summer. The crustaceans Thermocyclops oithonoides, Daphnia (D.) cristata, Bosmina (E.) cf. coregoni, and rotifers of the genus Asplanchna formed the basis of the summer plankton community of the entire lake. In all seasons, a large relic crustacean Limnocalanus macrurus was registered. Due to more favorable thermal and trophic conditions, a greater number of species were recorded in the southern reach (35 versus 27); they were mainly presented by cladocerans Limnosida frontosa, Sida crystallina, Daphnia (D.) galeata, Daphnia (D.) longispina, and Alonella nana. In addition, copepod Eurytemora lacustris and rotifer Lacinularia ismailoviensis were noted in the southern areas of the lake. Therefore, the zooplankton of Lake Munozero was represented by the species, which were usual for the deep lakes of Karelia. The species composition and dominant zooplankton complex of Lake Munozero has not changed since the 1950s, when comparing our results with the data obtained in previous years (Gordeeva-Pertseva, 1957; Il'mast et al. 2015; Kulikova, 2004;). The number of identifiable species (30-40) depended on the methodological peculiarities and study area.

The Shannon-Weaver index in terms of biomass ranged as $2.52-2.88$ from season to season in the northwestern reaches of the lake, in the southern reaches, from 2.18 to 2.81. According to I.N. Andronikova (1996), this range of index values corresponds to the oligo- and mesotrophic lake types.

The saprobity indices have been changing little: from 1.60 (spring) to 1.70 (summer - autumn) in the northwestern region of the lake, in the southern region, from 1.70 (spring and autumn) to 1.74 (summer). Saprobity indices correspond to the $\beta$-mesosaprobic zone, or moderately polluted water (Derevenskaya, 2015). In both lake areas, the share of mesotrophic indicator species ranged from $55 \%$ to $70 \%$ of the species list.

During the studied growing season, the abundance of zooplankton in the northwestern reach changed by 9 times, biomass, by 43 times; in the southern reach, 
Table 1. The species composition of the zooplankton of the pelagic zone of Lake Munozero by months.

\begin{tabular}{|c|c|c|c|c|c|c|c|c|}
\hline \multirow{2}{*}{ No. } & & \multirow{2}{*}{ Species } & \multicolumn{3}{|c|}{ North-western reach } & \multicolumn{3}{|c|}{ Southern reach } \\
\hline & & & $\mathrm{V}$ & VII & IX & V & VII & IX \\
\hline 1 & \multirow{8}{*}{$\begin{array}{l}\frac{\pi}{8} \\
\frac{0}{0} \\
0 \\
0\end{array}$} & Limnocalanus macrurus Sars, 1863 & + & + & + & + & + & + \\
\hline 2 & & Eudiaptomus gracilis (Sars, 1863) & + & + & + & + & + & + \\
\hline 3 & & Heterocope appendiculata Sars, 1863 & - & + & + & - & + & - \\
\hline 4 & & Eurytemora lacustris (Poppe, 1887) & - & - & - & - & + & - \\
\hline 5 & & Mesocyclops leuckarti (Claus, 1857) & + & + & + & + & + & + \\
\hline 6 & & Thermocyclops oithonoides (Sars, 1863) & + & + & + & + & + & + \\
\hline 7 & & Cyclops sp. & + & + & - & + & - & - \\
\hline 8 & & Acanthocyclops sp. & + & + & + & + & + & + \\
\hline 9 & \multirow{15}{*}{$\begin{array}{l}\frac{\pi}{0} \\
0 \\
\frac{0}{0} \\
\frac{\pi}{U}\end{array}$} & Diaphanosoma brachyurum (Liévin, 1848) & - & + & + & - & + & + \\
\hline 10 & & Limnosida frontosa Sars, 1862 & - & - & - & - & + & + \\
\hline 11 & & Sida crystallina (Müller, 1776) & - & - & - & - & - & + \\
\hline 12 & & Holopedium gibberum Zaddach, 1855 & + & + & + & + & + & + \\
\hline 13 & & Ceriodaphnia quadrangular (Müller, 1785) & - & + & + & - & + & + \\
\hline 14 & & Daphnia (Daphnia) cristata Sars, 1862 & - & + & + & - & + & + \\
\hline 15 & & D. (Daphnia) galeata Sars, 1864 & - & - & - & - & - & + \\
\hline 16 & & D. (Daphnia) longispina (Müller, 1785) & - & - & - & - & + & - \\
\hline 17 & & D. (Daphnia) longiremis Sars, 1862 & + & - & - & + & - & - \\
\hline 18 & & Bosmina (Bosmina) longirostris (Müller, 1785) & - & + & - & + & + & - \\
\hline 19 & & Bosmina (Eubosmina) cf. coregoni Baird, 1857 & - & + & + & - & + & + \\
\hline 20 & & Bosmina (Eubosmina) cf. Iongispina Leydig, 1860 & + & + & + & - & + & + \\
\hline 21 & & Alonella nana (Baird, 1850) & - & - & - & + & + & - \\
\hline 22 & & Leptodora kindtii (Focke, 1844) & - & + & - & - & + & + \\
\hline 23 & & Polyphemus pediculus (Linnaeus, 1761) & + & + & - & - & + & + \\
\hline 24 & \multirow{12}{*}{ 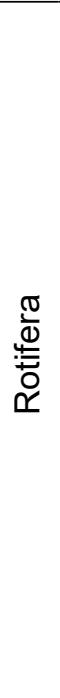 } & Bipalpus hudsoni (Imhof, 1891) & + & + & - & + & + & + \\
\hline 25 & & Conochilus unicornis Rousselet, 1892 & + & + & + & + & + & + \\
\hline 26 & & Filinia longiseta (Ehrenberg, 1834) & - & + & - & + & + & - \\
\hline 27 & & Kellicottia longispina (Kellicott, 1879) & + & + & + & + & + & + \\
\hline 28 & & Keratella cochlearis (Gosse,1851) & + & + & + & + & + & + \\
\hline 29 & & Keratella quadrata (Müller, 1786) & + & + & - & + & + & + \\
\hline 30 & & Lacinularia ismailoviensis (Poggenpol, 1872) & - & - & - & - & - & + \\
\hline 31 & & Polyarthra dolychoptera Idelson, 1925 & + & - & + & + & - & - \\
\hline 32 & & Polyarthra major Burckhardt, 1900 & - & + & - & - & + & - \\
\hline 33 & & Synchaeta pectinata Ehrenberg, 1832 & + & + & + & + & + & + \\
\hline 34 & & Asplanchna sp. & + & + & + & + & + & + \\
\hline 35 & & Philodina sp. & - & - & + & - & - & + \\
\hline
\end{tabular}


their values varied by 14 and 63 times, respectively (Table 2). The lowest values of quantitative parameters were observed in May, when zooplankton had not yet begun its active development. The maximum values in the northern reach were recorded in the summer, in the southern reach, in the autumn.

Such a difference may be explained by the time shift of the summer maximum of zooplankton in the reaches. Probably, a later start of the decline of the parameters in the southern area in autumn has been caused by more favorable thermal conditions.

Summer quantitative indicators of the lake zooplankton were comparable to those obtained in 2005 (Il'mast et al., 2015). According to the scale suggested by S.P. Kitaev (Kitaev, 2007), the summer biomass of zooplankton of the northwestern reach of the lake reflected the oligotrophic status of the plankton community; in the area of the southern reach, the $\alpha$-mesotrophic level in the summer and $\beta$-mesotrophic status in the autumn were observed, which indicated an increase in the food supply in this area. Probably, the high quantitative indicators registered in September 2018 were a consequence of the temperature regime of the certain year, but not the long-term characteristic of the lake.

Seasonal changes of the structure of zooplankton community of Lake Munozero are natural for the lakes of Karelia. Usually, the copepods form the basis of the zooplankton community in early spring and autumn (Table 3). When the water is warmed up in late spring, the role of rotifers increases; in the warm summer period, the number of cladocerans does do. The changes of the structure of zooplankton communities were not synchronous in the studied areas; during the survey period, they were at different phases of seasonal development. Regard must be paid to the

Table 2. Abundance and biomass of the zooplankton of Lake Munozero by seasons.

\begin{tabular}{|c|c|c|c|c|}
\hline \multirow[t]{3}{*}{ Season } & \multicolumn{2}{|c|}{ North-western reach } & \multicolumn{2}{|c|}{ Southern reach } \\
\hline & \multicolumn{4}{|c|}{ Abundance } \\
\hline & $10^{3}$ ind. $/ \mathrm{m}^{3}$ & $10^{3}$ ind. $/ \mathrm{m}^{2}$ & $10^{3}$ ind. $/ \mathrm{m}^{3}$ & $10^{3}$ ind.$/ \mathrm{m}^{2}$ \\
\hline Spring & 3.54 & 141.5 & 8.71 & 174.3 \\
\hline Summer & 31.54 & 1198.7 & 60.35 & 1207.0 \\
\hline \multirow[t]{2}{*}{ Autumn } & 10.37 & 415.0 & 119.04 & 1904.6 \\
\hline & \multicolumn{4}{|c|}{ Biomass } \\
\hline Spring & 0.020 & 0.79 & 0.048 & 0.96 \\
\hline Summer & 0.854 & 32.46 & 1.609 & 32.19 \\
\hline Autumn & 0.180 & 7.18 & 3.004 & 48.06 \\
\hline
\end{tabular}

Table 3. The ratio of the main groups of zooplankton (\%) by season.

\begin{tabular}{|c|c|c|c|c|c|c|}
\hline \multirow[t]{2}{*}{ Season } & \multicolumn{3}{|c|}{ North-western reach } & \multicolumn{3}{|c|}{ Southern reach } \\
\hline & Copepoda & Cladocera & Rotatoria & Copepoda & Cladocera & Rotatoria \\
\hline & \multicolumn{6}{|c|}{ Abundance } \\
\hline Spring & 58.0 & 1.2 & 40.7 & 37.8 & 3.2 & 59.1 \\
\hline Summer & 22.0 & 27.8 & 50.2 & 36.0 & 51.4 & 12.6 \\
\hline \multirow[t]{2}{*}{ Autumn } & 64.4 & 18.2 & 17.4 & 51.2 & 32.1 & 16.7 \\
\hline & \multicolumn{6}{|c|}{ Biomass } \\
\hline Spring & 77.2 & 5.5 & 17.3 & 51.4 & 10.9 & 37.7 \\
\hline Summer & 13.9 & 31.7 & 54.4 & 13.7 & 71.1 & 15.3 \\
\hline Autumn & 51.4 & 36.3 & 12.3 & 28.2 & 47.5 & 24.3 \\
\hline
\end{tabular}


dominating of cladocerans in the southern reach in the summer, which indicates a higher level of trophy than that observed in the northern reach.

The vertical distribution of zooplankton in the north-western and the southern areas was somewhat different. In spring, rotifers and copepods constituted the main part of the zooplankton community by abundance at all depths due to the dominance of Kellicottia longispina and Conochilus unicornis (Rotifera) and to the development of Thermocyclops oithonoides and nauplii of Cyclopida (Copepoda). More than a half (60$70 \%$ ) of the zooplankton community of the north-western and southern reaches were concentrated in the upper 5-m water layer (Fig. 1). In the spring, favorable temperature and trophic conditions evolve in the surface layers for the plankton development.

In summer, cladocerans and copepods dominated in the 0-10-m water layer. The main role belonged to Daphnia (D.) cristata, Bosmina (E.) cf. coregoni, and Thermocyclops oithonoides. In the southern part, the dominants were also Bosmina (E.) cf. longispina and Mesocyclops leuckarti. At the end of July, with heating of the water masses, the main part of the zooplankton kept in the 5-10-m water layer in both the north-western and the southern areas. In the north-western reach, rotifers Kellicottia longispina and Asplanchna sp. played the leading role. In the southern reach, three groups of zooplankton had an approximately equal share due to Bosmina (E.) cf. longispina, Daphnia (D.) cristata, species of the genus Asplanchna and nauplii of Cyclopoida in the water layer of 10-20 m.

In autumn, Eudiaptomus gracilis, Mesocyclops leuckarti, Thermocyclops oithonoides, and Daphnia (D.) cristata prevailed at all depths. In the north-western reach, Kellicottia longispina was also the dominant species; in the southern reach, they were Bosmina (E.) cf. coregoni and the species of the genus

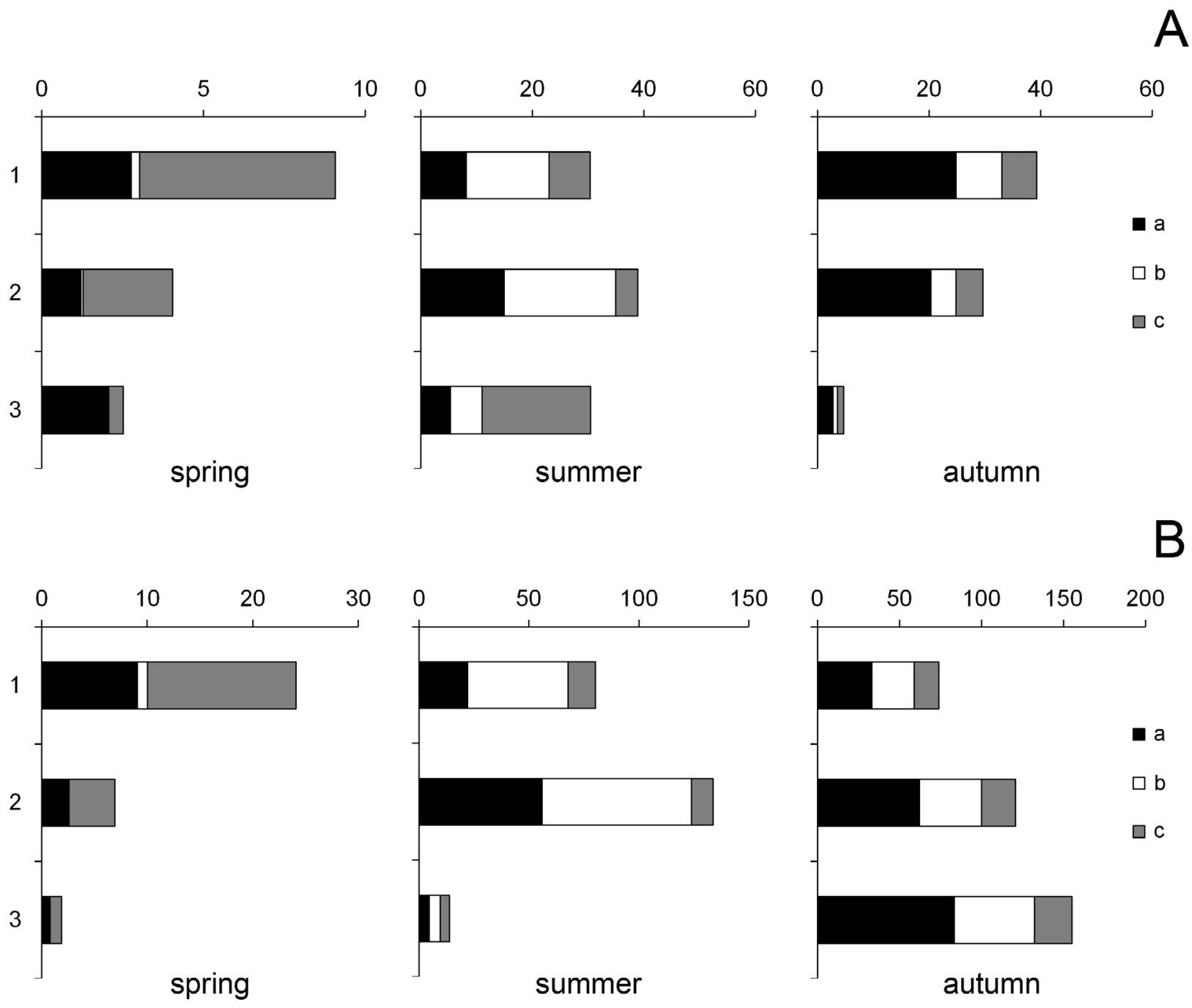

Fig. 1. Vertical distribution of the zooplankton abundance $\left(\mathrm{N}, 10^{3}\right.$ ind. $\left./ \mathrm{m}^{3}\right)$ in the north-western $(\mathbf{A})$ and southern $(\mathbf{B})$ reaches of Lake Munozero in different seasons. 1 - 0-5-m water layer; 2 - 5-10-m water layer; 3 - water layers deeper than 10 m; a - Copepoda; $b$ - Cladocera; $c$ Rotatoria. 
Table 4. Daily production, destruction, and ration $\left(\mathrm{kcal} \cdot \mathrm{m}^{-2} \cdot \mathrm{day}^{-1}\right)$ of the zooplankton community of Lake Munozero by season.

\begin{tabular}{ccccccc}
\hline \multirow{2}{*}{ Season } & \multicolumn{3}{c}{ North-western reach } & \multicolumn{3}{c}{ Southern reach } \\
& Production & Respiration & Ration & Production & Respiration & Ration \\
\hline Spring & 0.019 & 0.053 & 0.105 & 0.026 & 0.070 & 0.136 \\
Summer & 0.683 & 1.694 & 3.718 & 1.470 & 3.606 & 8.057 \\
Autumn & 0.151 & 0.628 & 1.214 & 1.279 & 3.799 & 7.993 \\
Daily average & 0.284 & 0.792 & 1.679 & 0.925 & 2.492 & 5.395 \\
\hline
\end{tabular}

Table 5. The total balance of the energy fluxes $\left(\mathrm{kcal} \cdot \mathrm{m}^{-2}\right)$ in the zooplankton community of Lake Munozero during the growing season.

\begin{tabular}{cccccc}
\hline Area & $\begin{array}{c}\text { Total production } \\
(\mathrm{P})\end{array}$ & $\begin{array}{c}\text { Total destruction } \\
(\mathrm{R})\end{array}$ & $\begin{array}{c}\text { Non-predator } \\
\text { ration (Cnp) }\end{array}$ & $\begin{array}{c}\text { Average } \\
\text { biomass (B) }\end{array}$ & P/B \\
\hline $\begin{array}{c}\text { North-western } \\
\text { reach }\end{array}$ & 38.0 & 105.0 & 197 & 6.7 & 5.6 \\
Southern reach & 123.0 & 331.0 & 625 & 13.5 & 9.1 \\
\hline
\end{tabular}

Asplanchna. The maximum zooplankton abundance in the north-western part of the lake was noted in the surface layer, similar to that in spring; in the southern part, in a water layer of $10-20 \mathrm{~m}$. In the southern reach, the share of cladocerans and the copepod Eudiaptomus gracilis was almost twofold higher than that in the north-western reach; this explained the difference in the vertical distribution of the zooplankton.

The functional characteristics of zooplankton reflect our ideas about the matter and energy fluxes in the studied community. The flux depends on the zooplankton biomass, the community structure, and ambient temperature. Daily production and other characteristics of the community were minimal in the spring, at low temperatures and when slowly growing copepods dominated. The maximum rates of consumption, destruction, and production of zooplankton in the north-western area were observed in the summer and then decreased markedly by autumn. The daily functional values for the zooplankton in the southern reach in July and September were approximately equal; most likely, their maxima occurred in August (between the sampling in July and September) (Table 4).

In general, the functioning of the zooplankton community in the southern part of the lake is more intense, which is ensured by better food availability for the filter-feeding species due to an increase in the lake trophicity (Sabylina and Ikko, 2019).

It is believed that the flow of matter and energy passing through the community of pelagic zooplankton is commensurate with the ration of non-predator filterfeeders (Table 5). A part of the matter and energy is lost during assimilation, a part is spent for the respiration, the rest forms secondary production and is used for the biomass increase (growth).

In Lake Munozero, the P/B coefficient, reflecting the intensity of production per unit of biomass, corresponded to oligotrophic type planktonic systems. The zooplankton productivity in the north-western part of Lake Munozero was almost three times less than that in the southern part (Table 5).

\section{Conclusions}

The species composition and dominant zooplankton complex of Lake Munozero has not changed since the 1950s. The Shannon-Weaver index in terms of biomass corresponds to the oligoand mesotrophic type of lakes in the northwestern and southern areas of the lake, respectively. Saprobity indicators refer to the $\beta$-mesosaprobic zone (moderately polluted water). Seasonal changes in the zooplankton community correspond to the dynamics common for the lakes of Karelia.

Zooplankton community of the southern reach of Lake Munozero is under anthropogenic load, which leads to noticeable differences in species composition, Shannon-Weaver index, saprobity index, and in quantitative and functional characteristics.

\section{Acknowledgments}

This work was carried out as part of the State Task of the Northern Water Problems Institute of the Karelian Research Center of the Russian Academy of Sciences. 


\section{References}

Adrian, R., Wilhelm, S., Gerten, D., 2006. Life-history traits of lake plankton species may govern their phenological response to climate warming. Global Change Biology 12, 652-661.

Alekseyev, V.R., Tsalolikhin, S.Ya. (eds.), 2010. Opredelitel zooplanktona i zoobentosa presnykh vod Evropeyskoy Rossii. T. 1. Zooplankton [The taxonomic keys for zooplankton and zoobenthos of the fresh waters of European Russia. Vol. 1. Zooplankton.]. KMK, Moscow, Russia, 495 p. (In Russian).

Andronikova, I.N., 1996. Strukturno-funktsionalnaya organizatsiya zooplanktona ozernykh ekosistem raznykh troficheskikh tipov [Structural and functional organization of zooplankton of lake ecosystems of different trophic types]. Nauka, Saint-Petersburg, 189 p. (In Russian).

Balushkina, E.V., Vinberg, G.G., 1979. Zavisimost mezhdu dlinoy i massoy tela planktonnykh rakoobraznykh [The relationship between the length and weight of plankton crustaceans]. In: Vinberg, G.G. (ed.), Eksperimentalnyie i polevyie issledovaniya biologicheskih osnov produktivnosti ozer [Experimental and field studies of the biological foundations of the lake productivity]. Nauka, Leningrad, USSR, 58-72. (In Russian).

Derevenskaya, O.Yu., 2015. Metody otsenki kachestva vod po gidrobiologicheskim pokazatelyam: uchebno-metodicheskaya razrabotka po kursu "Gidrobiologiya" [Methods for assessing water quality by hydrobiological indicators: educational and methodical development for the course "Hydrobiology"]. KFU, Kazan, Russia, 44 p. (In Russian).

Filatov, N.N., Kukharev, V.I. (eds.), 2013. Ozera Karelii. Spravochnik [Lakes of Karelia. Handbook]. Karelian Research Center of Russian Academy of Sciences, Petrozavodsk, Russia, 464 p. (In Russian).

Gordeeva-Pertseva, L.I., 1958. Gidrobiologicheskaya kharakteristika [Hydrobiological characteristic]. Rybnoye khozyaystvo Karelii [Fisheries of Karelia] 7, 107-117. (In Russian).

Il'mast, N.V., Kuchko, O.P., Milyanchuk, N.P., 2015. Vodnyye ekosistemy osobo okhranyayemykh prirodnykh territoriy Karelii [Water ecosystems of especially protected natural territories of Karelia]. Izvestiya Samarskogo nauchnogo tsentra Rossiyskoy akademii nauk [Proceedings of Samara Scientific Center of the Russian Academy of Sciences] 17 (6), 299-303. (In Russian).
Izmest'eva, L.R., Moore, M.V., Hampton, S.E., Ferwerda, C.J., Gray, D.K., Woo, K.H., Pislegina, H.V., Krashchuk, L.S., Shimaraeva, S.V., Silow, E.A., 2016. Lake-wide physical and biological trends associated with warming in Lake Baikal. Great Lakes Research 24, 6-17.

Jones, R.I., 1992. The influence of humic substances on lacustrine planktonic food chains. Hydrobiologia 229, 73-91.

Kalinkina, N.M., Tekanova, E.V., Sabylina, A.V., Ryzhakov, A.V., 2019. Izmeneniya gidrokhimicheskogo rezhima Onezhskogo ozera s nachala 1990-kh godov [Changes in the hydrochemical regime of Onego Lake since the early 1990s]. Izvestiya RAN. Seriya geograficheskaya [Proceedings of Russian Academy of Science, Geographical Series] 1, 6272. (In Russian). https://doi.org/10.31857/S258755662019162-72

Kitayev, S.P., 2007. Osnovy limnologii dlya gidrobiologov i ikhtiologov [Basics of limnology for hydrobiologists and ichthyologists]. Karelian Research Center of Russian Academy of Sciences, Petrozavodsk, Russia, 395 p. (In Russian).

Kulikova, T.P., 1983. Rekomendatsii po opredeleniyu saprobnosti $s$ uchetom biologicheskikh osobennostey planktonnykh organizmov Karelii [Recommendations for the determination of saprobity taking into account the biological features of planktonic organisms of Karelia]. Karelian Branch of Academy of Sciences of USSR, Petrozavodsk, Russia, 6 p. (In Russian).

Kulikova, T.P., 2004. Zooplankton vodnykh ob'ektov basseyna reki Shui (Kareliya) [Zooplankton of water bodies of the Shuya River basin (Karelia)]. Karelian Research Center of Russian Academy of Sciences, Petrozavodsk, Russia, 124 p. (In Russian).

Lazareva, V.I., Sokolova, E.A., 2013. Dinamika i fenologiya zooplanktona krupnogo ravninnogo vodokhranilishcha: otklik na izmeneniye klimata [Dynamics and phenology of zooplankton in a large plain reservoir: a response to climate changes]. Uspekhi sovremennoy biologii [Biology Bulletin Reviews] 133 (6), 564-574. (In Russian).

Nazarova, L.E., 2014. Izmenchivost srednikh mnogoletnikh znacheniy temperatury vozdukha $v$ Karelii [Variability of average long-term values of air temperature in Karelia.]. Izvestiya RGO [Proceedings of the Russian Geographical Society] 146 (4), 27-33. (In Russian). 
Rask, M., Appelberg, M., Hesthagen, T., Tammi, J., Beier, U., Lappalainen, A., 2000. Fish status survey of Nordic lakes - species composition, distribution, effects of environmental changes. TemaNord 508, $1-58$.

Soranno, P.A., Carpenter, S.R., He, X., 1993. Zooplankton biomass and body size. In: Carpenter, S.R., Kitchell, J.F. (eds), The trophic cascade in lakes. Cambridge University Press, Cambridge, Great Britain, 172-188.

Sabylina A.V., Ikko O.I., 2019. Otsenka tendentsiy izmeneniya himicheskih pokazateley vodyi ozera Munozero $v$ mnogoletnem plane [Evaluation of trends in the chemical indicators of the water of
Lake Munozero in a multi-year plan]. Trudy Kare/skogo nauchnogo centra RAN. Ser. Ekologicheskie issledovaniya [Proceedings of Karelian Research Center of Russian Academy of Sciences. Ecological studies series] 9, 79-60.

Vinberg, G.G., Lavrentyeva, G.M. (eds.), 1984. Metodicheskiye rekomendatsii po sboru i obrabotke materialov $v$ gidrobiologicheskikh issledovaniyakh na presnovodnykh vodoyemakh. Zooplankton i ego produktsiya [Methodological guidelines for collecting and processing materials for hydrobiological studies of freshwater reservoirs. Zooplankton and its production]. Berg State Research Institute on Lake and River Fisheries (GosNIORKh), Leningrad, USSR, 33 p. (In Russian). 